\title{
The notion of secularization: Drawing the boundaries of its contemporary scientific validity
}

Current Sociology Review

$1-19$

(C) The Author(s) 2014

Reprints and permissions:

sagepub.co.uk/journalsPermissions.nav DOI: 10.1177/001।3921।4533333

csi.sagepub.com

@SAGE

\author{
Alfonso Pérez-Agote \\ Universidad Complutense of Madrid, Spain
}

\begin{abstract}
The notion of secularization as an incompatibility between modernization and religion derives from the analysis of the process of modernization of Western European societies. This process led to a weight loss of religion in society and to a progressive differentiation of social spheres, such as religion, politics, science, etc. Following on from this analysis the category and the theory were extended to take on a universal scope in order to describe the modernization processes that would occur in other societies. From the very beginning, sociology has provided exceptions to the rule of secularization. The first was noted by de Tocqueville: American exceptionalism. Then came the processes of rapid economic growth of some Asian Pacific countries (Japan, Korea, Singapore, etc.). Progressively, the entry of new countries into the field of interest of sociologists is showing the Eurocentric nature of the concept. The case of Western Europe, which was the rule, became the exception. Even the notion of religion as a separate social sphere is considered by some social scientists to be ethnocentric. Despite its previous Eurocentrism, the notion of secularization remains useful for sociologists. It has served to account for European religious change, and its analytical instruments can be applied to other cases and may be useful for interpreting these cases either with regard to how they adhere to the Western European model, or how they differ from it - still further, if we consider the huge extent of contemporary international migration. If sociologists want to understand the new Western European societies, they must reapply this analytical rather than predictive version of the concept.
\end{abstract}

\section{Corresponding author:}

Alfonso Pérez-Agote, Universidad Complutense of Madrid, Campus de Somosaguas, Facultad Políticas y Sociología, Madrid, 28223, Spain.

Email: aperezag@cps.ucm.es 


\section{Keywords}

Eurocentrism, modernization, rationality, religion, religious change, religious culture, secularization, social differentiation

\section{Introduction}

The concept of the secularizing society has undergone many different historical transformations. As a sociological idea, secularization is the process pertaining to modern societies whereby religious doctrines and organizations experience diminished social influence because of the expansion of rationalism, science and technology that accompanies the process of industrialization and urbanization. This is a complex process that entails many individual, social and political dimensions within religion (Tschannen, 1992). The societal secularization thesis owes a great deal to learned ideas regarding the progress of human reason. It was developed as a theoretical argument during the 19th century, and as a part of the thought regarding the passing of traditional society. It was this analysis of the process of modernization that in turn was the very origin of the discipline of classic sociology. The reflection on the decline of religion in modern society is essential to the development of European sociology and remained intrinsic to it until the 1970s (Swatos and Christiano, 1999; Swatos and Olson, 2000). The concept of secularization was not as pronounced within American sociology due to the different model of modernization experienced by a country formed by successive migrations with diverse religious traditions. The need to accommodate the coexistence of many different religious creeds early on in the United States precluded the formation of a national Church.

The notion of secularization derives from the analysis of the process of modernization of Western European societies, leading to a progressive differentiation or separation between the various social spheres (religion, politics, science, marketplace, etc.); after this analysis the category and the theory were extended to take on a universal scope in order to describe the modernization processes that would occur in other societies. From very early on we see the emergence of exceptions to the supposed universality and transhistoricity of the notion and the theory, which progressively weaken the scope of its validity. Despite this Eurocentrism of the notion, it continues to have its uses because: (1) it has served to account for European religious change; (2) its analytical instruments can be applied to other cases, and may be useful for interpreting these cases either with regard to how they adhere to the Western European model, or how they differ from it. In this sense, sociologists must try to define more clearly the main analytical meanings of secularization, not in order to predict social phenomena in other societies, but to be able to use these meanings for an empirical analysis of their religious change. Other societies may or may not have levels of secularization; religion may or may not be separate from other spheres, and may or may not have lost importance in individuals' consciousness and behaviours; all this is significant material for analysis. Even at this micro level within Western European societies it is worth making a number of observations, as the loss of the importance of religion may not go hand in hand with a decline in religiosity or spirituality; and the decrease in individual religion may be accompanied by the emergence and success of new religious movements (Stark, 1993) (3). This analytical development 
of the notion can be applied to the analysis of the new situations occurring in Western European countries in general, and particularly as a consequence of immigration (specifically in the last quarter of the 20th century) from countries in which the differentiation of spheres has not occurred so patently as in the destination countries. This produces a desecularization in the destination countries, but, as indicated by Hammond and Shibley (1993), it represents not a return to an earlier situation, but a new phenomenon that requires analysis.

This way of approaching the concept highlights the fact that the theory of secularization is not a general theory of religious change, nor is it a universal theory, for the following two reasons: it cannot be applied in every case; and in the cases where it is useful, it does not consider the entire spectrum of changes that occur.

\section{The concept of secularization in sociology}

The term secularization had a long history before appearing in sociology. 'The medieval dichotomous classification of reality into religious and secular realms' was undermined by four processes that led to western modernity: 'the Protestant Reformation; the formation of modern states; the growth of modern capitalism; and the early modern scientific revolution' (Casanova, 1994: 20-21). The Enlightenment, in the 18th century, brought an awareness of the progressive disappearance of religion from society. Sociology, in the 19th and 20th centuries, developed this idea further by analysing the processes of modernization within European societies (Casanova, 1994: Ch. 1; Dianteill and Löwy, 2005; Hervieu-Léger and Willaime, 2001; Nisbet, 1974; Shiner, 1967; Turner, 1996).

The emerging social sciences in the 19th century collaborated actively in the process of nation-state building of European secular societies (Lefort, 2006). Sociologists' participation in this process is the reason why secularization was classified as an irreversible social process but never as an ideology or as a political project or movement. Certain anthropologists appreciated 'that secularism is not a disenchanted political stand that consists of abstract principles and that the promotion of secularism is not an innocuous plea for public neutrality vis-à-vis the plurality of beliefs and worldviews. Secularism is carried by social actors with specific interests who associate it with concrete lifestyles, emotionally identify with it, sacralize it in the image of the state and of the founding fathers, performatively display their adherence to it, and mobilize against religious movements through complex strategies' (Gorski and Altinordu, 2008: 73; see also Asad, 2003, 2006; Navaro-Yashin, 2002). As Beckford (2003) said, many early sociologists were involved in political and practical schemes to clarify, obstruct or assist the decline of religion's significance.

The most important sociologists of the 19th and early 20th centuries prophesized the future decline of religious institutions, but also foresaw a conceptual and very important analytical device for us to understand the changes in the role that religion plays in society. Later, in the 1970s, Bell warned us that a simple and linear notion of secularization could no longer be admitted as an inexorable quantitative disappearance of religious beliefs, but that we should consider instead secularization to be something complex and multiple and not necessarily universal (Bell, 1977). The time had come to discuss the assumption that the relationship between modernism and religion is necessarily 
conflictual. Some, at one extreme, advocated that the thesis of secularization should be abandoned definitively (Stark, 1999); for others, at the other extreme, it remained valid, although in need of some revision. And in the middle, there were more and more proponents of a review of religion's relationship with its social environment: 'modern religion is resilient and subject to cultural influences; it does not merely survive or decline, but adapts to its environment in complex ways' (Wuthnow, 1988: 475).

\section{Dimensions of secularization}

Bellah (1964) constructs an evolutionary typology that underscores the importance of a series of aspects that are implicit in the notion of religion and religious change as envisaged by European sociology. This typology is sustained by the notion of the progressive functional differentiation of society in general, particularly along the lines of developing symbolic differentiation, based on Voegelin's (1956) fundamental idea that society evolves from compactly symbolized forms into differentiated forms. Bellah distinguishes five fundamental historical types. The first two are primitive and archaic religions, corresponding to barely differentiated forms of society. In the primitive type there is no differentiated religious organization: Church and Society are one and the same; while in the archaic type the religious organization is amalgamated with other social structures. Cosmological monism occurs in both the primitive and archaic types. The rupture of this monism, through the discovery of a field of religious reality, is precisely the main characteristic of historic religion, the third type. This represents the appearance of rejection of this world, of the mundane, while characterizing religious action as something that is requisite to the individual's salvation. This differentiated religious organization is distinguished from the political organization and hierarchy, and also implies that the problem of legitimizing political power has entered a new phase: there is now the possibility that political acts can be judged in religious terms. Early modern religion is the fourth type. The advent of religious modernism derives from the Protestant Reformation, whose fundamental characteristic was the collapse of the hierarchical structuring of the two worlds. We should not search for salvation in withdrawal from this world but instead at the centre of worldly activities. The fifth and final type, modern religion, is generically characterized by Bellah as the collapse of dualism, so crucial to historical religions. But this would not mean the return to archaic or primitive monism. Bellah characterizes as profoundly intellectual the quest for understanding modern religious symbolization. Kant is at the core of this reflection having posited that there are not merely two dichotomous religious and secular realms, but rather as many worlds as there are ways of apprehending them. At the level of mass religion, it is not clear whether individuals actually require cognitive harmony, i.e. internal consistency in their beliefs.

The evolutionary nature of this typology should serve as a cautionary note. It is perhaps more valuable for understanding the historical development of religion within the Occident than such processes within non-western societies; nonetheless, all types have intrinsic analytical interest. Furthermore, as we know, even within western contexts, the institutionalization and meaning of religion changes over time. In particular, the separation of religion from other institutions has been the result of a historical process. When we examine non-western societies, it might be that their religion is not segregated from 
such other institutions as culture, knowledge and politics. In the present western societies, when individuals and institutions from diverse religious backgrounds come into contact there is the strong possibility of misunderstanding and tension. In France, for example, when a young immigrant wears her Islamic veil, as far as the French are concerned she is displaying a religious symbol (Roy, 2010). Nevertheless, to forbid her dress is, for her community, the proscription of an undifferentiated symbol that is simultaneously religious, cultural, family-based and political. At the heart of the matter is the danger of employing the category of religion ethnocentrically, as we shall see in the final section.

\section{Successive exceptions to the rule of secularization}

The sociological thesis of the contradiction between modernism and religion has undergone a series of historical periods, each of which comes up with an exception to the rule until contemporary times, when secularization became the exception and the survival of religion became the rule. A first exception to the idea of the contradiction between modernity and religion which dominated classical sociological thought was highlighted by de Tocqueville in De la démocratie en Amérique (1835-1840). When faced with the thesis that religion and modernism are incompatible, he always invoked as the exception the case of the United States (de Tocqueville, 1981). Its religiosity was one aspect of socalled American exceptionalism (Bellah, 1967; Ross, 1984; Tyrrell, 1991). The US, despite being an industrialized, urbanized, rationalized society, is also characterized by its "periodical mass or public renewals of the religious life and, stemming from Puritanism, ... the diffusion of religious elements to other social contexts. ... The three major religious orientations - Protestantism, Catholicism, and Judaism - not only fill an important niche as providers of social identity but also have found in the United States an exceptional historical setting' (Tiryakian, 1993: 40).

The economic development of some Asian Pacific countries (Japan, Korea, Singapore, etc.) has provided good reason to rethink the relationships between religion and modernism. These countries, which currently have such powerful economies, have become westernized, although it is no less true that despite this they are not western. For example, Dore has demonstrated substantial differences between Japan and the West, differences which themselves account for the Japanese economic miracle, and in so doing he has shown that individualism is not a necessary condition for modernism (Dore, 1992). All of these countries have incorporated their traditions into modernism. This leads us to conclude that the value of the classic secularization theory was not so much in its ability to describe all reality but its utility in the analysis of certain historical societies.

Considering the cases of the aforementioned countries, as well as those of the two large contemporary Asian economies, India and China, we can identify one of the key factors for rethinking the theory of secularization in our times: to reassess, at the same time, the theory of modernization. The most recent reviews converge upon the conclusion, posited in detail by Eisenstadt (1998, 2000, 2001), that there are many paths to modernity. The "modern patterns, different in many radical ways from the "original" European ones (Martin, 1979), crystallized not only in non-Western societies, ... but also - indeed first of all - within the framework of the Western expansion in societies in 
which seemingly purely Western institutional frameworks developed - in the Americas' (Eisenstadt, 2001: 4-5).

\section{Europe: The rule which becomes the exception}

There is currently a convergence (Berger, 1992; Davie, 2001; Hervieu-Léger, 1996, 2001; Martin, 1996) towards the consideration of Europe 'as the only geographic and cultural area (maybe alongside Canada) in which the typical ideal schema of secularization as the expulsion of religion can be applied, as opposed to the other continents, including the United States' (Hervieu-Léger, 2001: 7). Paradoxically, Peter Berger (1967), one of the most relevant contemporary theoreticians of secularization, recently produced the following diagnosis of the situation of religion in our world in general and in Europe in particular: 'The current world is massively religious; it is anything but the secularized world which had been announced by so many modernity analysts. There are two exceptions to this proposal. ... The first apparent exception is Western Europe, where the old theory of secularization seems to still be applicable. ... The other exception is much less ambiguous: there is an international sub-culture of people who have received Western style higher education, particularly in humanities and social sciences, which is actually secularized' (Berger, 2001: 24-26).

Grace Davie, based on surveys from 1986 and 1990 by the EVSSG (European Values Systems Study Group), proposes as a general trend in Europe the progressive weakening of religious practice, institutional adhesion and acceptance of traditional religious beliefs. However, she then adds that the clearest difference that occurs within Europe is the separation of the Catholic countries in the South, which are more religious (with the exception of France) from the Protestant countries in the North, which are less religious (with the exceptions of the Republic of Ireland and Northern Ireland) (Davie, 2001: 108-109). This means that while there is discernible secularization in both regions, it was earlier and stronger in the North than in the South (with the aforementioned exceptions).

Catholic countries in the South of Europe have formed a zone of greater resistance to religious and political modernization, with both dimensions being broadly connected (Pérez-Agote, 2012b). Furthermore, analysis of countries in this area has led to interesting theoretical formulations: religious culture (Hervieu-Léger, 2003), implicit religion (Nesti, 1990), religious ground base (Bellah, 1980) and diffuse religion (Cipriani, 1989). The case of France is special: in classifications, it is sometimes included among countries with a Catholic tradition (Davie, 1996) while at others it is considered as the uniquely laïcal country par excellence (Stoetzel, 1983).

\section{The persistence of religion in Western Europe}

It is true - as maintained by Grace Davie - that Western Europe is undergoing a strong downward trend in religious practice, adhesion to institutions and acceptance of beliefs, all of which affect the dominant confessions in these countries. However it is equally true that new processes and trends have also arisen and are shaping the religious landscape in these countries. Casanova, in 1984, highlighted four important aspects of the persistence of religion in the western world. The first involved the new religious movements that 
emerged from the counterculture of the 1960s, primarily in the United States but also in Europe; their social breeding ground was among the most educated and financially wellplaced sectors of the population, and their ideas were predominantly linked to a Christian tradition, which set them apart from the religious revivals frequently seen in American society. The second aspect of the religious renewal outlined by Casanova is the resurgence of Protestant fundamentalism in the United States; this new fundamentalism tends to sacralize the bourgeois values inherent in the liberal phase of capitalism and thus also inclines towards the dismantling of state interventionism. In 1972 Kelley had already indicated that while the five main Protestant families that were fundamental to the ecumenical movement of the day were in decline, the conservative branches of certain denominations were gaining in importance at the same time (Kelley, 1986: 17-35). Iannaccone, following his rational choice assumptions, demonstrated how 'the strength of strict churches is neither a historical coincidence nor a statistical artifact. Strictness makes organizations stronger and more attractive because it reduces free riding. It screens out members who lack commitment and stimulates participation among those who remain. Rational choice theory thus explains the success of sects, cults, and conservative denominations without recourse to assumptions of irrationality, abnormality, or misinformation' (Iannaccone, 1994: 1180). The third aspect mentioned by Casanova concerns the phenomenon of the renewal of the great historical official Churches. The author illustrates his case with the various renewal operations undergone by the Catholic Church, namely the Second Vatican Council, and liberation theology which emerged against the backdrop of Latin America. In fourth place he refers to what is known as the 'human potential movement', which comprises a series of psychologizing practices dedicated to developing individual well-being and equilibrium. This case also includes a number of regressions to archaic forms of religiosity (astrology, spiritualism, occultism, Satanism, etc.), and - more significantly - the substantial growth in what Luckmann (1967) has termed 'invisible religion' (Casanova, 1984). These three forms (the human potential movement, regressions to archaic forms and invisible religion) constitute a trend towards what could be described as the 'individualization of religion'.

To gain a complex vision of the process of secularization in the West we need to examine the different ways in which religion has lost its importance in the individual sphere. This is the fourth aspect raised by Casanova. A first form is the disappearance of religion from the symbolic individual universe: individuals who totally abandon religion or new generations of individuals who have no dealings with religion at all. A second form is the one theorized by Luckmann (1967) in The Invisible Religion: within individually maintained forms of religiosity, he distinguishes between those that are not oriented towards a Church and those that are. This distinction between religion and Church (Besecke, 2005) thus becomes central, and the fact that the strength of the various Churches is in decline (Chaves, 1994) does not necessarily imply that the same is true of religion. Invisible religion may exist without any reference to a specific Church or creed, and there may also be invisible religion in people who have gradually disassociated themselves from the religion they used to profess and from its corresponding Church, and have arrived at a more or less indeterminate religious situation.

This last case has been theorized in Europe in terms of 'believing without belonging'. Voas and Crockett maintain that this expression, coined by Grace Davie $(1990,1994)$, 
'has become the catchphrase of much European work on religion in the past decade', referring to the 1990s (Voas and Crockett, 2005: 11). The proportion of believers in Europe has probably decreased less than the proportion of individuals who belong to different and corresponding religious confessions. If this is so, then generally speaking Europeans have conserved their belief in God and their religious (or, at least spiritual) sensibility; but their religious practice, as an indicator of belonging, has declined more substantially. This formulation comes up against two deep-seated problems. The first is that an individual's belief in God and religious or spiritual sensibility may not be associated with the specific religion and Church to which he or she belonged in the past; the term 'belief' may refer to a specific historic and institutionalized religion, or to something which involves the supernatural, or the spiritual at the extreme, without reference to a specific and institutionalized set of beliefs. The second problem involves determining what the indicators of belonging to a specific institution are. 'At least outside the boundaries of religion, no one expects assent to any given view to be matched by active membership in a relevant organization' (Voas and Crockett, 2005: 13). There are various ways of expressing belonging; without doubt one way is participation in rituals of maintenance, which we normally call religious practice; but there are weaker or less active forms of manifestation of belonging, such as the mere statement by an individual of belonging to a specific religion. A variant of this last form could be a response to a question on belonging in a survey. Belonging to an institution is not a clear and simple phenomenon. In the first place it should be said that different forms may imply different degrees of belonging. Hirschman (1970: Chs 7 and 8) proposes three basic forms: loyalty, exit and internal opposition and protest; but there is also obviously a wide spectrum of possible intermediate forms and processes of internal change towards the institution.

Here we need to distinguish between maintaining beliefs and maintaining a coded set of beliefs, since the latter implies a greater degree of practice and belonging than the first.

What lies at the heart of the meaning of the expression 'believing without belonging' is the issue of orthodoxy. A religious creed, controlled by an institution called 'the Church', requires, in order to maintain itself without any substantial modifications, the attendance of believers at its rituals of maintenance; the increasing drop-off in attendance by believers at these rituals leads to an increasing heterodoxy in the original creed. Thus the expression 'believing without belonging' is misleading, as it may lead to the impression that belief (its maintenance in terms of orthodoxy) is independent of practice.

An alternative formulation to the juxtaposition of belief and belonging derives from the notions of 'religious culture' and 'exculturation' (Hervieu-Léger, 2003). Some European countries with a Catholic religion have gradually evolved into countries with a Catholic culture. Religious practice is declining in these countries, and the orthodoxy of the creed is being eroded to the point that belief in certain elements of the Catholic creed is dying out, while belief in others persists. What is disappearing is the belief in the creed as a total entity; and this creed is the symbolic capital of the institution we call the Church, which therefore guards it zealously. Religion, a specific religious creed, has an institutionalization, whereas culture - understood here as the plurality of a series of shared meanings within a social reality - has a much weaker level of institutionalization. 
There is no single visible institution charged with safeguarding the maintenance of culture, although there are many concerned with safeguarding the maintenance of parcels of culture. Culture, in general, is maintained by the pure and simple use that individuals make of it. For this reason, in France or Spain, for example, the preserved beliefs that derive from the Catholic creed, insofar as they are maintained without reference to the ecclesiastical institution, have now become part of the culture, without ecclesiastical mediation; and they are as much a part of the culture as other elements that come from science, politics or other spheres of society (Pérez-Agote, 2012a: 119-125; Swartz, 1996).

The notion of Catholic culture opens up the possibility of exploring how the gradual weakening of religion may persist in the phenomenon that Hervieu-Léger, discussing the French case, has termed 'exculturation'; this is the 'process whereby, beyond the manifest decline in the Church's influence in society, the profane culture is losing its Catholic fabric' (2003: 87). The underlying process is decatholization, which is practically equivalent to a decrease in religious observance. Exculturation is a process in which culture, in the sense of shared representations, gradually loses its religious roots; religion has permeated a society's culture; culture has become detached from its strictly religious nature, but this culture continues to be infused by religion. The next step is the progressive loss of the Catholic roots of that culture. The notions of religious culture and exculturation have also been applied in the Spanish case, where the notions of family, work and profession, and the representation of death itself, have lost their religious roots in young people of recent generations (Pérez-Agote, 2012a: 138-139, 323-324).

These aspects appear to endorse Wilson's idea that individual secularization is the process whereby the 'Churches are losing influence over the ideas and activities of men' (1969: 22). If we accept this definition, we also accept the idea that individual secularization does not necessarily imply the disappearance of religion from people's lives; when this disappearance does occur, secularization occurs; but secularization also occurs when, without disappearing, individuals cease to be controlled in the sphere of their ideas and behaviours by a Church, and religiosity is transferred to the purely individual realm. On the other hand, secularization does not occur when a Church ceases to have control over certain individuals because they create their own institution (religious protest movements) or convert to another Church. Thus individual secularization could be defined as the death or deinstitutionalization of religion.

To the four aspects of the social life in Western Europe mentioned by Casanova, we could now add two new types of phenomenon that have had a profound effect on the religious landscape of the area since the last quarter of the 20th century.

In the first place, this period has seen an intensification in transnational immigration. The so-called oil crisis drastically altered the conditions of the immigrant population already present and the entry conditions for future immigrants. In addition, the fall of the Soviet empire triggered a strong trend in the population of Eastern Europe to emigrate to the West. Since the recent turn of the century the countries of Southern Europe have become receiving countries. The immigrant population has thus continued to rise, and to contribute to the process of religious pluralization in Western Europe. The economic hardships that have accompanied certain phases of this process have had significant consequences on the conditions of social integration for people of immigrant origin, and this 
has no doubt substantially modified the social uses that this population makes of its original religion in terms of cultural identity and pragmatic solidarity. Some religions that were previously unknown in Western Europe have come to form part of the European religions, thus shattering the traditional religious homogeneity of these countries (Kepel, 1987; Lamine, 2004; Roy, 2005). This heralds a new religious plurality in European countries. Also at this time the new 1965 immigration law in the United States repealed the restrictive laws of the 1920 s, thereby recovering the old immigrant tradition of the 19 th century. However the origins of this new influx were significantly different: Latin America, Asia and, increasingly, all the regions in the world (Casanova, 2007: 59). These new transnational migratory currents have had very different social and political consequences on each side of the Atlantic, in view of the dissimilar cultural, political and religious traditions prevailing on each shore (Banchoff, 2007; Berger, 2007; Wuthnow, 2007).

A look at Western Europe highlights one of the general consequences that has occurred due to the inflow of population from societies with a clearly lower level of subjective secularization, and where the degree of separation and differentiation between culture and religion is limited or even non-existent. This has created specific conflicts in the cultural and religious field. Nowadays, symbols that are regarded as religious by the native population constitute religious-cultural-political symbols (all at the same time) in a population that has not undergone the same process of social differentiation as in Western Europe. The modern idea of nation was a way of secularizing the legitimacy of power (Pérez-Agote, 2006: Ch. 2). Moreover, as Bellah says, 'every nation and every people come to some form of religious self-understanding' (1991: 168). Some authors even speak of nationalism as the religion of modernity (Santiago, 2009). This means that the historical problem of separation between Church and State as a central enclave in the process of democratization of the national state is giving way to the new issue of the different degrees of separation between culture and religion in the autochthonous and immigrant population, as we have seen in speaking of the Islamic veil (Roy, 2010). The idea of secularism of the state cannot be the same in a situation where society is no longer homogeneous from a religious point of view. Other ways of thinking secularism are emerging, such as the notion of open secularism (Bouchard and Taylor, 2008: 43-49).

In second place, it is worth highlighting the, in some cases highly belligerent, responses by the Churches that have historically been entrenched in these countries to laws passed by Western European governments on divorce, abortion, same-sex marriage (and the adoption of children), assisted reproduction, euthanasia and stem cell research since the last quarter of the 20th century. This has led to a reappraisal of the stance of some of these Churches in relation to the public political sphere (Dobbelaere and PérezAgote, in press).

\section{Other religions, other countries}

The rapid development process that occurred in a series of non-western countries employing certain elements of their traditional culture as a productive resource led some sociologists to examine the possibility that there are different ways to modernize. The pragmatic theory of multiple modernization processes represents a rupture with the idea 
that a religious crisis is requisite to the attainment of modernity. Nowadays, the increasingly relevant evidence that we are living in a globalized world and the progressive development of sociological analysis in more and more places throughout the world mean that sociology is raising the question of relationships between modernity and religion in relation to other non-Christian religions as well as non-western societies.

We find issues raised as a consequence of the latest waves of immigration, particularly Muslim, reaching Western Europe countries (Kepel, 1987; Lamine, 2004; Roy, 2005). Over the last few years, particularly following the attacks on 11 September 2001, which shook the world, much literature has been produced on Islamic fundamentalism. Some have even gone so far as to suggest possible incompatibility between Islam and the democratic organization of society. Particularly within political science, there has been an attempt to specify the conditions that a religion and a political organization must meet in order to produce the 'twin tolerations' - that is 'the minimal boundaries of freedom of action that must somehow be crafted for political institutions vis-à-vis religious authorities, and for religious individuals and groups vis-à-vis political institutions' (Stepan, 2000: 37). Casanova has compared 'the contemporary global discourse on Islam as a fundamentalist and undemocratic religion' with 'the old discourse on Catholicism that predominated in Anglo-Protestant societies, particularly in the United States' (Casanova, 2005: 89).

Muslim emigration to Europe has had serious consequences. Some religious demands have provoked political conflict (Göle, 2006). Some cultural practices relating to sexual discrimination, ablation, the veil and arranged marriages have been widely discussed (Benhabib, 2002; Scott, 2007; Shweder et al., 2002). The issue of the Muslim veil in France and in Turkey has given rise to interesting studies (De Galembert, 2009; Gaspard and Khosrokhavar, 1995; Gökariksel and Mitchell, 2005). Fetzer and Soper (2005) compare how their differing perceptions of the relationship between Church and State affects how well Muslim immigrants adapt in Great Britain, France and Germany. On the other hand, migration has effected among Muslims a profound cultural (Wieviorka, 1998) and religious (Cesari, 2004; Roy, 2004; Tietze, 2002) transformation, and a marked expansion of the social functions of religion (Pérez-Agote and Santiago, 2009).

We should add that the World Values Survey has made it possible to analyse the religious situation in some countries for which there was no systematic sociological information until now, which in turn makes it possible to effect comparative analyses. Gorski and Altinordu (2009: 65) give us a vision of the wide range of derived conclusions:

At first glance, the data hardly suggest decline; on the contrary, they indicate increase (Antoun \& Hegland 1987, Sahliyeh 1990). This has led Berger and others to argue that the world is currently in a period of desecularization (Berger 2001; Karner and Aldridge 2004). Norris and Inglehart $(2004 ; 2007)$ reject this view and develop an ingenious defense of secularization theory. On the one hand, they say, growing levels of existential security in certain countries and population segments have led to declining levels of religiosity; on the other hand, high levels of religiosity continue to be correlated with high rates of fertility. If aggregate levels of religiosity are increasing, they argue, this is the result of demographic forces, not of putative desecularization. But what about the Euro- American divide? This divide is explained by the strength of the welfare state (high security) in Europe and the persistence of laissez-faire liberalism (low security) in the United States. 
Our main conclusion is that we should equip ourselves with analytical instruments with which to better understand the varied situations in which religion is found all across the world and over time. From the perspective of religious change, the notion of secularization should be treated in analytical terms thereby avoiding the suppositions of universality and transhistoricity, and the teleological pretension as well. This is necessary due to religion's demonstrated capacity to adapt to change and, for this same reason, due to the variety of situations and processes that crop up in the world given this adaptive capability.

\section{Towards an analytical framework of religious change}

Dobbelaere (2002) designed an analytical framework at the three levels of macro, meso and micro. Societal secularization, the macro level, refers to relationships between society and religion, and specifically to the process by which religion is pushed towards increasingly marginal zones of modern western societies. On the one hand, this produces a rupture in the unity of the traditional sacred cosmos and, on the other, the progressive liberation of specific spheres of social life from its former religious guardianship. This dimension of secularization enters with full force into the purview of the social differentiation process (Dobbelaere, 2002: 29). Nevertheless, secularization, as a process for rationalizing the spheres of life, goes beyond economics to touch upon religion itself. Consequently, its organizational dimension, the meso level, inclines towards progressive rationalism and to its adaptation to changes; it is religion itself and its organization that are secularized and thereby adapt to the changes (Dobbelaere, 2002: 35). For this reason, this dimension has been called internal secularization by Luckmann (1967). The individual dimension, the micro level, refers to the process whereby individuals' religious beliefs and practices are decreasing substantially, and the capability of religion and a Church to determine their behaviour is also contracting.

The individual dimension of secularization tells us about the relationships between three institutional levels of religious life. The decline of religion in the individual sphere implies loss of importance for a specific institution made up of a specific historical religion and the corresponding Church; but it does not necessarily imply the collapse of religiosity (belief in God, religious experience, etc.); if religiosity survives while religion and the Church dwindle, individuals will have to construct their sense of life and verify it intersubjectively; religiosity would become deinstitutionalized.

Each of the three dimensions has a certain analytical, and even empirical, independence, as they can entail different and even contradictory processes. But they are also interrelated. Precisely by establishing the possible theoretical relationships between the three, we are building a very interesting set of instruments from an analytical point of view.

\section{Religion, as a differentiated sphere, is a problematic category}

Nowadays, the consideration of the European case as just one of many, rather than as the universal way which must be taken, affects not only the area of religion but also many 
others. But some basic concepts of social science are taking longer than others to be reviewed; this is what is happening with religion. Peter van der Veer and Hartmut Lehmann point out that "it is important to realize that both "nation" and "religion" are conceptualized as universal categories in Western modernity and that their universality is located precisely in the history of the Western expansion. The modernity of the concept of the nation needs little discussion beyond mentioning the relationship between the ideas of "nation" and "ethnicity" as raised by the reference to "birth" in the very word nation. The modernity of the concept of religion, as applied in the modern era to Hinduism, Shintoism, Islam, but also Christianity, is much less an accepted truism in the social sciences' (Van der Veer and Lehmann, 1999: 4; see also De Vries, 2008a, 2008b).

The most radical criticism of the very notion of religion is that made by Talal Asad. This author attempts to demonstrate that it is impossible for social science to make a universal, transhistorical definition of religion. To do this he takes as an example the definition given by Clifford Geertz (1973) as a system of symbols. In the 1980s, Asad had already criticized this definition with the accusation that "with its emphasis on meanings ... it omits the crucial dimension of power, ... ignores the varying social conditions for the production of knowledge'. And 'its initial plausibility derives from the fact that it resembles the privatised forms of religion so characteristic of modern (Christian) society, in which power and knowledge are no longer significantly generated by religious institutions' (Asad, 1983: 237). Twenty years later, Asad goes further and considers that considering religion as a separate sphere from social life has no meaning outside the notion of the secular. In an Islamic society it makes no sense to talk of religion as a separate sphere from politics. The secular is a creation of western societies as part of a modernization project on a planetary scale. And this means that secularism is the western project to separate religion from the rest of social life; a project for both western and non-western societies. Asad is not only considering non-western societies but also the western ones. This separation has not always existed in the West, as the case in medieval Christianity shows (Asad, 2003: 1-17). But it is not clear either that it exists in contemporary western societies. He attempts to demonstrate this when he mentions the theoretical position of José Casanova on the relationships between religion and politics. 'Casanova points to three elements in that thesis [secularization] all of which have been taken - at least since Weber - to be essential to the development of modernity: (1) increasing structural differentiation of social spaces resulting in the separation of religion from politics, economy, science, and so forth; (2) the privatization of religion within its own sphere; and (3) the declining social significance of religious belief, commitment, and institutions. Casanova holds that only elements (1) and (3) are viable.' For Casanova, 'the deprivatization of religion is not a refutation of the thesis if it occurs in ways that are consistent with the basic requirements of modern society, including democratic government. In other words, although the privatization of religion ... is part of secularization, it is not essential to modernity.' And Asad adds that Casanova's position 'is not an entirely coherent one. For if the legitimate role for the deprivatized religion is carried out effectively ... elements (1) and (3) are both ... undermined.' With the legitimate entry of religion into the debates about economy, education and science, the principle of structural differentiation no longer holds. And with 'the passionate commitments these debates 
engender, it makes little sense to measure the social significance of religion only in terms of such indices as church attendance' (Asad, 2003: 181-182; Casanova, 2006).

In much nineteenth-century evolutionary thought, religion was considered to be an early human condition from which modern law, science and politics emerged and became detached. In this [twentieth] century most anthropologists have abandoned Victorian evolutionary ideas, and many have challenged the rationalist notion that religion is simply a primitive and therefore outmoded form of the institutions we now encounter in truer form (law, politics, science) in modern life. For these twentieth- century anthropologists, it is not an archaic mode of scientific thinking, nor of any other secular endeavor today; it is, on the contrary, a distinctive space of human practice and belief which cannot be reduced to any other. From this it seems to follow that the essence of religion is not to be confused with, say, the essence of politics, although in many societies the two may overlap and intertwine. (Asad, 2002 [1982]: 115)

For Asad the relationships between religion and politics have never completely ceased to exist, since he considers that religion is always mixed with politics and power, even when these are constitutionally separate in western countries. Asad takes as his own the idea that 'the public domain is not simply a forum for rational debate but an exclusionary space. ... the public sphere is a space necessarily (nor just contingently) articulated by power' (Asad, 2003: 183-184). And he quotes Robert Wolff (1969: 52) when he discusses the public sphere: 'if an interest falls outside the circle of the acceptable, it receives no attention whatsoever and its proponents are treated as crackpots, extremists, or foreign agents'.

\section{Funding}

This research received no specific grant from any funding agency in the public, commercial, or not-for-profit sectors.

\section{References}

Antoun RT and Hegland ME (1987) Religious Resurgence: Contemporary Cases in Islam, Christianity, and Judaism. Syracuse, NY: Syracuse University Press.

Asad T (1983) Anthropological conceptions of religion: Reflections on Geertz. Man, New Series, 18(2): 237-259.

Asad T (2002 [1982]) The construction of religion as an anthropological category. In: Lambeck M (ed.) A Reader of Anthropology of Religion. Malden, MA: Blackwell, pp. 114-132.

Asad T (2003) Formations of the Secular: Christianity, Islam, Modernity. Stanford, CA: Stanford University Press.

Asad T (2006) Trying to understand French secularism. In: De Vries H (ed.) Political Theologies. New York: Fordham University Press, pp. 494-526.

Banchoff T (ed.) (2007) The New Religious Pluralism and Democracy. New York: Oxford University Press.

Beckford JA (2003) Social Theory and Religion. Cambridge: Cambridge University Press.

Bell D (1977) The return of the sacred? The argument of the future of religion. British Journal of Sociology 28(4): 419-449.

Bellah RN (1964) Religious evolution. American Sociological Review 29: 358-374.

Bellah RN (1967) Civil religion in America. Daedalus 96(1): 1-21. 
Bellah RN (1980) The five religious of modern Italy. In: Bellah RN and Hammond PE (eds) Varieties of Civil Religion. San Francisco: Harper and Row, pp. 86-118.

Bellah RN (1991) Beyond Belief: Essays on Religion in a Post-traditionalist World. Berkeley: University of California Press.

Benhabib S (2002) The Claims of Culture: Equality and Diversity in the Global Era. Princeton, NJ: Princeton University Press.

Berger PL (1967) The Sacred Canopy: Elements of a Sociological Theory of Religion. New York: Doubleday.

Berger P (1992) A Far Glory: The Quest for Faith in an Age of Credulity. New York: Doubleday. Berger P (2001) La désécularisation du monde: un point de vue global. In: Berger P (ed.) Le Réenchantement du monde. Paris: Bayard, pp. 13-36.

Berger P (2007) Pluralism, protestantization, and the voluntary principle. In: Banchoff T (ed.) The New Religious Pluralism and Democracy. New York: Oxford University Press, pp. 19-29.

Besecke K (2005) Seeing invisible religion: Religion as societal conversation about transcendent meaning. Sociological Theory 23(2): 179-196.

Bouchard G and Taylor C (2008) Building the future: A time for reconciliation (abridged report). Available at: red.pucp.edu.pe/wp-content/uploads/biblioteca/buildingthefutureGerardBouchardycharlestaylor.pdf.

Casanova J (1984) The politics of religious revival. Telos 20: 3-33.

Casanova J (1994) Public Religions in the Modern World. Chicago: University of Chicago Press.

Casanova J (2005) Catholic and Muslim politics in comparative perspective. Taiwan Journal of Democracy 1(2): 89-108.

Casanova J (2006) Secularization revisited: A reply to Talal Asad. In: Scott D and Hirschkind C (eds) Powers of the Secular Modern: Talal Asad and His Interlocutors. Stanford, CA: Stanford University Press, pp. 12-30.

Casanova J (2007) Immigration and the new religious pluralism: A EU/US comparison. In: Banchoff T (ed.) The New Religious Pluralism and Democracy. New York: Oxford University Press, pp. 59-83.

Cesari J (2004) When Islam and Democracy Meet: Muslims in Europe and in the United States. New York: Palgrave Macmillan.

Chaves M (1994) Secularization as declining religious authority. Social Forces 72: 749-774.

Cipriani R (1989) 'Diffused religion' and new values in Italy. In: Beckford JA and Luckmann T (eds) The Changing Face of Religion. London: Sage, pp. 24-48.

Davie G (1990) Believing without belonging: It is the future of religion in Britain? Social Compass 37(4): 455-469.

Davie G (1994) Religion in Britain since 1945: Believing without Belonging. Oxford: Blackwell.

Davie G (1996) Contrastes dans l'héritage religieux de l'Europe. In: Davie G and Hervieu-Léger D (eds) Identités religieuses en Europe. Paris: La Découverte, pp. 43-62.

Davie G (2001) Europe: l'exception qui confirme la règle. In: Berger P (ed.) Le Réenchantement du monde. Paris: Bayard, pp. 99-128.

De Galembert C (2009) Cause du voile et lutte pour la parole musulmane légitime. Sociétés Contemporaines 74(2): 19-47.

De Tocqueville A (1981) De la démocratie en Amérique. Paris: GF Flammarion.

De Vries H (2008a) Introduction: Why still 'religion'? In: De Vries H (ed.) Religion: Beyond the Concept. New York: Fordham University Press, pp. 1-98.

De Vries H (ed.) (2008b) Religion: Beyond the Concept. New York: Fordham University Press.

Dianteill E and Löwy M (2005) Sociologies et religion. Approches dissidentes. Paris: Presses Universitaires de France.

Dobbelaere K (2002) Secularization: An Analysis at Three Levels. Brussels: PIE-Peter Lang. 
Dobbelaere K and Pérez-Agote A (in press) The Intimate: New Conflicts between Religion and Polity.Laws about Life, Death and the Family in So-called Catholic Countries. Leuven: Leuven University Press.

Dore R (1992) Sovereign individuals. In: Hall JA and Jarvie IC (eds) Transition to Modernity: Essays on Power, Wealth and Belief. Cambridge: Cambridge University Press.

Eisenstadt SN (1998) Multiple modernities in an age of globalization. Verhandlungen des 29 Kongressers der Deutschen Gessellschaft fur Soziologie 37-50.

Eisenstadt SN (2000) Multiple modernities. Daedalus 129(1): 1-29.

Eisenstadt SN (2001) The contemporary religious sphere in the context of multiple modernities. In: 1st Meeting of Eurosecularity Project, Berlin.

Fetzer JS and Soper JC (2005) Muslims and the State in Britain, France, and Germany. Cambridge: Cambridge University Press.

Gaspard F and Khosrokhavar F (1995) Le Foulard et la république. Paris: La Découverte.

Geertz C (1973) The Interpretation of Cultures. New Haven, CT: Yale University Press.

Gökariksel B and Mitchell K (2005) Veiling, secularism, and the neoliberal subject: National narratives and supranational desires in Turkey and France. Global Networks 5(2): 147-165.

Göle N (2006) Islam in European publics: Secularism and cultural difference. Hedgehog Review 8: $140-145$.

Gorski PS and Altinordu A (2008) After secularization? Annual Review of Sociology 34: 55-85.

Hammond PE and Shibley MA (1993) When the sacred returns: An empirical test. In: Barker D, Beckford JA and Dobbelaere K (eds) Secularization, Rationalism, and Sectarianism. Oxford: Clarendon Press, pp. 37-45.

Hervieu-Léger D (1996) La religion des européens: Modernité, religion, sécularisation. In: Davie G and Hervieu-Léger D (eds) Identités religieuses en Europe. Paris: La Découverte, pp. 9-25.

Hervieu-Léger D (2001) Faut-il continuer à débattre de la 'sécularisation'? In: 1st Meeting of Eurosecularity Project, working paper, Berlin.

Hervieu-Léger D (2003) Catholicisme, la fin d'un monde. Paris: Bayard.

Hervieu-Léger D and Willaime J-P (2001) Sociologies et religion. Approches classiques. Paris: Presses Universitaires de France.

Hirschman AO (1970) Exit, Voice, and Loyalty: Responses to Decline in Firms, Organizations, and States. Cambridge, MA: Harvard University Press.

Iannaccone LR (1994) Why strict churches are strong. American Journal of Sociology 99(5): $1180-1211$.

Karner C and Aldridge A (2004) Theorizing religion in a globalizing world. International Journal of Politics, Culture and Society 18(1-2): 5-32.

Kelley DM (1986) Why Conservative Churches Are Growing: A Study in the Sociology of Religion. Macon, GA: Mercer University Press.

Kepel G (1987) L'Islam des des banlieues: naissance d'une religion en France. Paris: Seuil.

Lamine AS (2004) La Cohabitation des dieux: pluralisme religieux et laïcité. Paris: Presses Universitaires de France.

Lefort C (2006) The permanence of theologico-political? In: De Vries H (ed.) Political Theologies. New York: Fordham University Press, pp. 148-186.

Luckmann T (1967) The Invisible Religion: The Problem of Religion in Modern Society. New York: Macmillan.

Martin D (1979) A General Theory of Secularization. New York: Harper.

Martin D (1996) Remise en question de la théorie de la sécularisation. In: Davie G and HervieuLéger D (eds) Identités religieuses en Europe. Paris: La Découverte, pp. 25-42.

Navaro-Yashin Y (2002) Faces of the State: Secularism and Public Life in Turkey. Princeton, NJ: Princeton University Press. 
Nesti A (1990) Implicit religion: The issues dynamics of a phenomenon. Social Compass 37(4): 423-438.

Nisbet RA (1974) The Sociology of Emile Durkheim. New York: Oxford University Press.

Norris P and Inglehart R (2004) Sacred and Secular: Religion and Politics Worldwide. New York: Cambridge University Press.

Norris P and Inglehart R (2007) Uneven secularization in the United States and Western Europe.

In: Banchoff T (ed.) The New Religious Pluralism and Democracy. New York: Oxford University Press, pp. 31-57.

Pérez-Agote A (2006) The Social Roots of Basque Nationalism. Reno: University of Nevada Press

Pérez-Agote A (2012a) Cambio religioso en España. Los avatares de la secularización. Madrid:

Centro de Investigaciones Sociológicas.

Pérez-Agote A (ed.) (2012b) Portraits du catholicisme. Une comparaison européenne. Rennes:

Presses Universitaires de Rennes.

Pérez-Agote A and Santiago J (2009) La nueva pluralidad religiosa. Madrid: Ministerio de Justicia.

Ross D (1984) Historical consciousness in nineteenth-century America. American Historical Review 89 (October): 909-928.

Roy O (2004) Globalized Islam: The Search for a New Ummah. New York: Columbia University Press.

Roy O (2005) La Laïcité face à l'islam. Paris: Stock.

Roy O (2010) Holy Ignorance: When Religion and Culture Part Ways. New York: Columbia University Press.

Sahliyeh EF (1990) Religious Resurgence and Politics in the Contemporary World. Albany: SUNY Press.

Santiago J (2009) From 'civil religion' to nationalism as the religion of the modern times: Rethinking a complex relationship. Journal for the Scientific Study of Religion 48(2): 394 401.

Scott JW (2007) The Politics of the Veil. Princeton, NJ: Princeton University Press.

Shiner L (1967) The concept of secularization in empirical research. Journal for the Scientific Study of Religion 6(2): 207-220.

Shweder R, Minow M and Markus HR (eds) (2002) Engaging Cultural Differences: The Multicultural Challenge in Liberal Democracies. New York: Russell Sage Foundation.

Stark R (1993) Europe's receptivity to new religious movements: Round two. Journal for the Scientific Study of Religion 32(4): 389-397.

Stark R (1999) Secularization RIP. Sociology of Religion 62(2): 249-273.

Stepan A (2000) Religion, democracy, and the 'twin tolerations'. Journal of Democracy 11(4): $37-57$.

Stoetzel J (1983) Les Valeurs du temps présent: une enquête européenne. Paris: Presses Universitaires de France.

Swartz D (1996) Bridging the study of culture and religion: Pierre Bourdieu's political economy of symbolic power. Sociology of Religion 57(1): 71-85.

Swatos WH and Christiano KJ (1999) Introduction - Secularization theory: The course of a concept. Sociology of Religion 60(3): 209-228.

Swatos WH and Olson DV (eds) (2000) The Secularization Debate. Lanham, MD: Rowman and Littlefield.

Tietze N (2002) Jeunes musulmans de France et d'Allemagne. Les constructions subjectives de l'identité. Paris: L'Harmattan.

Tiryakian E (1993) American religious exceptionalism: A reconsideration. Annals of the American Academy of Political and Social Science 527 (May): 40-54.

Tschannen O (1992) Les Théories de la sécularisation. Geneva: Droz. 
Turner BS (1996) For Weber: Essays on the Sociology of Fate. London: Sage.

Tyrrell I (1991) American exceptionalism in an age of international history. American Historical Review 96 (October): 1031-1055.

Van der Veer P and Lehmann H (eds) (1999) Nation and Religion: Perspectives on Europe and Asia. Princeton, NJ: Princeton University Press.

Voas D and Crockett A (2005) Religion in Britain: Neither believing nor belonging. Sociology 39(1): 11-28.

Voegelin E (1956) Order and History. Baton Rouge: Louisiana State University.

Wieviorka M (1998) Le multiculturalisme est-il la réponse? Cahiers Internationaux de Sociologie 105: 233-260.

Wilson B (1969) Religion in Secular Society. Harmondsworth: Pelican.

Wolff RP (1969) Beyond tolerance. In: Wolff RP, Moore B Jr and Marcuse H (eds) A Critique of Pure Tolerance. London: Cape.

Wuthnow RJ (1988) Sociology of religion. In: Smelser NJ (ed.) Handbook of Sociology. Newbury Park, CA, London and New Delhi: Sage.

Wuthnow RJ (2007) Religious diversity in a 'Christian nation': American identity and American democracy. In: Banchoff T (ed.) The New Religious Pluralism and Democracy. New York: Oxford University Press, pp. 151-167.

\section{Author biography}

Alfonso Pérez-Agote is Professor of Sociology at the Universidad Complutense of Madrid. He is the coordinator of the GERICR (Groupe Européen de Recherche Interdisciplinaire sur le Changement Religieux). His books include: The Intimate: New Conflicts between Religion and Polity. Laws about Life, Death and the Family in so-called Catholic Countries (with K Dobbelaere, eds) (in print), Cambio religioso en España. Los avatares de la secularización (2012), Portraits du Catholicisme. Une comparaison européenne (2012, ed.), La nueva pluralidad religiosa (2009, with J Santiago), Religión y politica en la sociedad actual (2008, with J Santiago, eds) and The Social Roots of Basque Nationalism (2006).

\section{Résumé}

La notion de laïcisation, considérée comme l'incompatibilité de la modernisation et de la religion, trouve son origine dans l'analyse du processus de modernisation des sociétés européennes occidentales. Ce processus a conduit à l'affaiblissement de la religion dans la société et à une progressive différenciation des sphères sociales, telles que la religion, la politique, la science, etc. Ces théories et ces catégories ont été généralisées pour en affirmer la portée universelle et décrire les processus de modernisation qui devraient survenir dans d'autre sociétés. Dès les premiers temps de son histoire, la sociologie a signalé des exceptions à la règle de la laïcisation. La première a été rapportée par Tocqueville : l'Exceptionnalisme américain. Ce fut ensuite la rapide croissance économique de certains pays de la région Asie-Pacifique (Japon, Corée, Singapour, etc.). L'intérêt des sociologues pour ces nouveaux pays a progressivement démontré la nature « eurocentrique » du concept. Le cas de l'Europe occidentale qui était autrefois la norme est devenu l'exception. La notion même de religion comme sphère sociale séparée est considérée comme ethnocentrique par certains chercheurs en sciences sociales. Malgré son eurocentrisme passé, la notion de laïcisation conserve néanmoins son utilité pour les sociologues. Elle permet de rendre compte des changements religieux européens 
et ses instruments analytiques peuvent s'appliquer à d'autres cas pour en interpréter les similitudes et les différences avec le modèle européen occidental. Elle peut s'avérer encore plus utile pour l'étude de la grande migration internationale contemporaine. Si les sociologues souhaitent comprendre les nouvelles sociétés européennes occidentales, ils devraient utiliser les outils analytiques et non prédictifs du concept.

\section{Mots-clés}

Modernisation, rationalité, religion, changement religieux, religiosité, culture religieuse, laïcisation, différenciation sociale

\section{Resumen}

El concepto de la secularización como una incompatibilidad entre la modernización y la religión deriva del análisis del proceso de modernización de las sociedades de Europa occidental . Este proceso dio lugar a una pérdida de peso de la religión en la sociedad y a una progresiva diferenciación de esferas sociales, como la religión , la política, la ciencia, etc. Después de este análisis, la categoría y la teoría se extendieron hasta asumir un alcance universal con la finalidad de describir los procesos de modernización que se producirían en otras sociedades. Desde el principio, la sociología ha proporcionado excepciones a la regla de la secularización. El primero fue observado por Tocqueville: el excepcionalismo estadounidense. Luego vinieron los procesos de rápido crecimiento económico de algunos países del Pacífico asiático (Japón, Corea, Singapur, etc.) Progresivamente, la entrada de nuevos países en el campo de interés de los sociólogos está mostrando el carácter eurocéntrico del concepto. El caso de Europa Occidental, que era la regla, se convirtió en la excepción. Incluso la noción de la religión como esfera social separada es considerada etnocéntrica por algunos científicos sociales. A pesar de su eurocentrismo originario, la noción de secularización conserva su utilidad para los sociólogos. Ha servido para dar cuenta de los cambios religiosos europeos y sus instrumentos de análisis pueden ser aplicados a otros casos, y puede ser útil para la interpretación de dichos casos, ya sea con respecto a la forma en que se adhieren al modelo europeo occidental, o cómo se diferencian de ella. Más aún, si tenemos en cuenta la gran migración internacional contemporánea. Si los sociólogos quieren entender las nuevas sociedades de Europa occidental, deben volver a aplicar esta versión analítica y no predictiva del concepto.

\section{Palabras clave}

Modernización, racionalidad, religión, cambio religioso, religiosidad, cultura, secularización religiosa, diferenciación social 